\title{
Different Conceptualizations of River Basins to Inform Management of Environmental Flows
}

\author{
Ben Gawne ${ }^{1 *}$, Samantha J. Capon ${ }^{2}$, Jenni Hale ${ }^{3}$, Shane S. Brooks ${ }^{4}$, Cherie Campbell ${ }^{5}$, \\ Michael J. Stewardson ${ }^{6}$, Mike R. Grace ${ }^{7}$, Rick J. Stoffels ${ }^{8}$, Fiorenzo Guarino ${ }^{1}$ and \\ Penny Everingham ${ }^{9}$ \\ ${ }^{1}$ Institute for Applied Ecology, University of Canberra, Bruce, ACT, Australia, ${ }^{2}$ Australian Rivers Institute, Griffith University, \\ Nathan, QLD, Australia, ${ }^{3}$ Independent Researcher, Wandong, VIC, Australia, ${ }^{4}$ Independent Researcher, Warrandyte South, \\ VIC, Australia, ${ }^{5}$ Murray Darling Freshwater Research Centre, La Trobe University, Mildura, VIC, Australia, ${ }^{6}$ Melbourne School \\ of Engineering, University Melbourne, Melbourne, VIC, Australia, ${ }^{7}$ Water Studies Center, School of Chemistry, Monash \\ University, Clayton, VIC, Australia, ${ }^{8}$ CSIRO Land and Water, Wodonga, VIC, Australia, ${ }^{9}$ Independent Researcher, Wooragee, \\ VIC, Australia
}

OPEN ACCESS

Edited by:

David Tickner,

World Wide Fund for Nature,

United Kingdom

Reviewed by:

Dustin E. Garrick,

University of Oxford, United Kingdom

Teresa Ferreira,

Universidade de Lisboa, Portugal

*Correspondence:

Ben Gawne

Ben.Gawne@canberra.edu.au

Specialty section:

This article was submitted to

Freshwater Science,

a section of the journa

Frontiers in Environmental Science

Received: 26 January 2018 Accepted: 13 September 2018

Published: 11 October 2018

Citation:

Gawne B, Capon SJ, Hale J, Brooks SS, Campbell C,

Stewardson MJ, Grace MR,

Stoffels RJ, Guarino F and

Everingham P (2018) Different Conceptualizations of River Basins to Inform Management of Environmental

Flows. Front. Environ. Sci. 6:111.

doi: 10.3389/fenvs.2018.00111
Environmental flows are a critical tool for addressing ecological degradation of river systems brought about by increasing demand for limited water resources. The importance of basin scale management of environmental flows has long been recognized as necessary if managers are to achieve social, economic, and environmental objectives. The challenges in managing environmental flows are now emerging and include the time taken for changes to become manifest, uncertainty around large-scale responses to environmental flows and that most interventions take place at smaller scales. The purpose of this paper is to describe how conceptual models can be used to inform the development, and subsequent evaluation of ecological objectives for environmental flows at the basin scale. Objective setting is the key initial step in environmental flow planning and subsequently provides a foundation for effective adaptive management. We use the implementation of the Basin Plan in Australia's Murray-Darling Basin (MDB) as an example of the role of conceptual models in the development of environmental flow objectives and subsequent development of intervention monitoring and evaluation, key steps in the adaptive management of environmental flows. The implementation of the Basin Plan was based on the best science available at the time, however, this was focused on ecosystem responses to environmental flows. The monitoring has started to reveal that limitations in our conceptualization of the basin may reduce the likelihood of achieving of basin scale objectives. One of the strengths of the Basin Plan approach was that it included multiple conceptual models informing environmental flow management. The experience in the MDB suggests that the development of multiple conceptual models at the basin scale will help increase the likelihood that basin-scale objectives will be achieved.

Keywords: environmental flow, river, restoration, degradation, adaptive management

\section{INTRODUCTION}

The increasing demand for water resources globally means that social, economic and environmental objectives are not being met, particularly when freshwater ecosystems are already severely degraded in many areas (Vorosmarty and Sahagian, 2000). Given strong hydrological connectivity of water resources throughout a river basin, and particularly the dependence of 
downstream communities on management of the upstream catchment, demands a basin-scale approach to planning sustainable water resource systems. A number of strategies have been proposed and implemented to address and seek long term sustainable water resource use over catchment and basin scales including Integrated Water Resource Management (Vorosmarty et al., 2013), Strategic Adaptive Management (Freitag et al., 2014; Laub et al., 2015), Socio-ecohydrological management (Falkenmark and Folke, 2002) among others (Stewardson et al., 2017). The successful implementation of all these approaches relies on there being adequate and accessible information to inform water planning decisions at the basin-scale (Huntjens et al., 2010; OECD, 2011; Neto et al., 2018).

Lack of, or incomplete information concerning the flow regimes required to sustain environmental values at both local and basin scales represents a significant threat to sustainable water management. The science of river restoration and environmental flows is, however, relatively young (Poff and Matthews, 2013) and while the importance of understanding large scale, long-term processes is recognized (McCluney et al., 2014; Thorp, 2014; Vorosmarty et al., 2015), it remains an emerging challenge (Poff and Matthews, 2013). Historically, environmental flows science and practice has focused more on the conservation of single species, progressing to consider ecosystems and then regions (Poff and Matthews, 2013). More recently there has been some theoretical consideration of river macro-systems; networks of connected and interacting habitat patches (McCluney et al., 2014). Given the large-scale implications of climate change, incorporating such basin-scale thinking into river management is more critical than ever for sustaining ecosystems and human communities into the future.

The broad range of scales, from meters to $1000 \mathrm{~km}$ at which freshwater systems operate demands that managers need to understand the role of environmental flows in sustaining environmental values at each scale (Soranno et al., 2010; Palmer et al., 2014; van den Belt and Blake, 2015). This represents a further challenge for managers for several reasons. First, ecological theory for larger scales is limited (Heffernan et al., 2014). Second, the larger the spatial scale, the longer the time scale over which the effects of flow regime changes will generally take place (Poff et al., 2017). For example, changes in channel morphology may take decades to stabilize (Vietz and Finlayson, 2017), while other changes may occur rapidly in response to severe events such as extreme floods (Friedman and Lee, 2002; Nelson and Dub, 2016) or anoxic blackwater events (Whitworth and Baldwin, 2016; Watts et al., 2018). Third, there have been limited opportunities to examine large-scale responses to changes in flow regimes and in particular introduction of environmental flows. Most published experimental environmental flow studies deal with individual rivers, with many restricted to a single reach downstream of a large dam (Olden et al., 2014). The monitoring of these environmental flows is also constrained, with many projects focusing on monitoring short-term outcomes of flow events rather than long-term responses to flow regimes (Olden et al., 2014; Flotemersch et al., 2016). As a consequence, uncertainty in system responses increases with scale, with greatest uncertainty associated with catchment or basin scale environmental flow responses.

One of the consequences of uncertainty at basin scales is that it affects managers' capacity to undertake smaller scale interventions that contribute to basin scale objectives. The risks associated with undertaking numerous small-scale restoration activities to achieve large scale outcomes have been recognized for some time (Bernhardt et al., 2007; Kondolf et al., 2008). One of the ways of managing this risk is to identify the contribution that the small-scale restoration activity is expected to make to achieve the larger scale objective; a task that is aided by the development of conceptual models (Kondolf et al., 2008).

The purpose of this paper is to describe how conceptual models can be used to inform the development, and subsequent evaluation of ecological objectives for environmental flows at the Basin scale. Objective-setting is the key initial step in environmental flow planning (Horne et al., 2017) and subsequently provides an input into adaptation of the basin scale water management framework and a foundation for effective adaptive management of environmental flows including monitoring and evaluation. We use the example of ongoing environmental flow management in Australia’s Murray Darling Basin (MDBA, 2011a; Hart, 2016) to illustrate the main points because it is one of the first examples of a flow restoration project seeking to plan, deliver and evaluate environmental flows across an entire river basin (Poff and Matthews, 2013; Olden et al., 2014; Stewardson et al., 2017). We begin by examining the approach taken to setting objectives for environmental flows and identifying the emerging limitations with a particular emphasis on basin scale matters. We then further develop the conceptualization proposed by McCluney et al. (2014) to consider the variety of conceptual models available to be adapted to inform adaptive environmental flow management at the basin scale. Finally, we discuss ways in which inclusion of a basin-scale conceptualization in environmental objectives may influence both management and evaluation of environmental flows drawing in the example of the MurrayDarling Basin.

\section{CONTEXT}

The MDB, in Australia's south-east, covers just over 1 million $\mathrm{km}^{2}, 14 \%$ of the total area of the continent (Crabb, 1997) and supports $50 \%$ of Australian irrigated agriculture and 2 million people (Roshier and Reid, 2002; Kingsford et al., 2013; Hart and Davidson, 2017). The Basin spans four states and the Australian Capital Territory, and as with dryland rivers around the world, flow is highly variable. The condition of the Basin's water dependent ecosystems has declined in response to multiple stressors (Walker et al., 1994; Davies et al., 2008). In response, Australian governments implemented the National Water Initiative and the Federal government passed the Water Act that required development of the Murray-Darling Basin Plan (Capon, 2014). The Basin Plan seeks to optimize social, 
economic, and environmental outcomes through the integrated management of water resources within a long-term adaptive management framework. A key element of the Plan was acquisition of water entitlements to contribute to a healthy and working Murray-Darling Basin.

The Basin Plan requires development of a long-term adaptive management framework that includes monitoring of the outcomes and evaluation of their contribution to achievement of Basin Plan objectives (MDBA, 2011a; Gawne et al., 2013). Effective monitoring programs are based on management objectives, a conceptual model, availability or feasibility of collecting data and stakeholder interest (McCluney et al., 2014). The monitoring needs to include hydrological, hydraulic and environmental response indicators (McCoy et al., 2018), however, here we focus on environmental response indicators.

Planning, allocating, and delivering environmental flows have been informed by the environmental objectives identified in the Basin Plan, specifically the protection and restoration of water dependent ecosystems and species of conservation significance (MDBA, 2011a). This objective is operationalized for environmental flow planning and management based on three considerations. The first is, an evaluation of the way flow regimes have been modified. Second, a focus on important environmental assets (e.g., Ramsar listed wetlands) and their water requirements. Third, and nested within the ecosystem approach, is the use of established species' flow requirements as surrogates for ecosystem water requirements. Species included are long-lived vegetation (River red gum, Black box) and colonial nesting waterbird breeding (Swirepik et al., 2016). This approach is complemented by the incorporation of the specific water requirements of species of conservation significance (e.g., southern golden bell frogs, Litoria raniformis Bino et al., 2018 Murray hardyhead fish, Craterocephalus fluviatilis Wedderburn et al., 2013).

The ecosystem approach focuses attention on the ecosystem as a discrete ecological entity rather than a component of a larger system (Capon and Capon, 2017). The approach taken to environmental flows in the MDB is similar to that used in other major river restoration initiatives around the world. This is where environmental flows have been allocated to meet the requirements of riparian (Porse et al., 2015) and wetland (Sklar et al., 2001; Lane et al., 2015) vegetation, fish, (Dodrill et al., 2015; McCoy et al., 2018), and waterbirds (Gaff et al., 2000; Wingard and Lorenz, 2014).

The approach taken in the MDB reflected common practice around the globe (Olden et al., 2014), however, the focus on ecosystems and species diverts attention away from the connections between ecosystems which although known, were not incorporated into the conceptual models that informed environmental flow management. The following are three examples of large scale or tele-connections known to act across the Basin. Many rivers in the southern basin experience anoxic blackwater events when floodwaters return to the main channel and have the potential to adversely affect fish communities hundreds of kilometers downstream (Whitworth et al., 2012; Watts et al., 2018). The second example is native fish, which are known to be capable of long distance movements for some time
(Reynolds, 1983). As technology has enabled improved tracking of fish it has become clear that for at least some species, long distance movements are important in breeding (Koster et al., 2017) and re-colonization of disturbed habitats (Thiem et al., 2017). The third example is waterbirds who have long been known to disperse long distances in search of suitable habitat (Frith, 1957, 1963; Roshier et al., 2001). Flow is an important influence on these movements at a variety of scales whether it be providing a network of habitats that act as dispersal corridors (Dorfman and Kingsford, 2001; Roshier et al., 2001) or foraging (Roshier and Reid, 2002; Kingsford et al., 2013) and/or refuge habitats in adjacent river basins (Wen et al., 2016).

As the outcomes of environmental flows in the MBD have been evaluated (Gawne et al., 2016, 2017), it has become apparent that these types of relationships may well be important in linking short-term outcomes to achievement of Basin Plan objectives. This raises the question of why these connections were not included in the initial conceptualization. There are likely several reasons including that the approach was a common approach used in other systems, including the Murray River where environmental flows had already achieved significant shortterm outcomes (MDBA, 2011b). Second, that compared to what was known about ecosystem and species water requirements, relatively little was known about tele-connections or their water requirements. With the information emerging from the monitoring and the adaptive management framework, there is increasing attention being directed toward thinking about the long-term context for the short-term environmental flows and implications for environmental flow management and evaluation.

McCluney et al. (2014) proposed a macrosystem conceptualization based on functional process zones (hydrogeomorphic patches). This model appears to align with the blackwater example above, but it is not clear to what extent it applies to waterbirds (and their passengers Figuerola and Green, 2002) or native fish. Given this and the possibility that each river basin may require its own conceptualization, the next section of the paper provides an overview of current understanding and conceptualization of river basins and their characteristics.

\section{River Basin Models}

River basins have been conceptualized in a wide variety of models (e.g., River Continuum Concept; Vannote et al., 1980) which vary in their descriptions of basin-scale properties and processes and how these might interact to produce basin-scale responses to anthropogenic pressures and management interventions. These contrasting perspectives are positioned along a continuum from a null hypothesis (i.e., that a river basin is not a system at all but rather an aggregation of smaller-scale systems) through to more holistic views in which everything is interdependent and any small change has the capacity to exert an influence at a basinscale. Along this continuum, different river basin models also vary with respect to the level of importance ascribed to different parts of the system and the connections among them (Panel 1).

The most obvious and straightforward way to characterize a river basin is with a linear accumulation of its constituent 


\section{PANEL 1 | Models of Basin-scale ecological structure and function}

River basins can be conceptualized differently with implications for prioritization, monitoring and evaluation of environmental flows. Model selection may differ depending on management objectives or decision-maker preferences. Four major conceptual models are:

\section{1. "Black boxes"}

The simplest conceptualization of a river basin is as a "black box," i.e., a single unit with inputs and outputs and particular attributes, e.g., the size, type, number, and diversity of components etc. This model assumes the basin is a system but ascribes no significance to the distribution of, or relationships among components and processes.

Application of this model to environmental flow management leads to the development of targets associated with input (e.g., flow volumes) and outputs (e.g., fish production or end of valley salt loads). Variable responses to equivalent management interventions are likely to be difficult to explain under this model.

\section{River basins as "plum puddings"}

Socio-politically, river basins are often conceived as being comprised of assets. This can range from a small number of large assets (plum pudding model); i.e., a relatively non-significant matrix in which iconic or significant sites are embedded. This model is reflected by many broad-scale conservation approaches, e.g., National Reserve systems, Ramsar sites, etc.

This model sits at the more holistic end of the conceptualization spectrum and suggests two options for monitoring:

1) If plums are high value assets whose function is to sustain values then the condition of basin-scale values could be evaluated by aggregating the condition of plums. Effect of flows on plums would be monitored and that would be sufficient.

2) If plums are sources of biota supplying a sink matrix, then both plum response and their connections with the rest of system may be monitored.

\section{River basins as linear networks}

River networks are linear, heterogeneous, continuous, and hierarchical (Fausch et al., 2002) and longitudinal patterns are important. Linear networks are a useful framework for considering in-stream processes: fish migration, nutrient cycling, stream metabolism etc. This view of river basins is epitomized by river continuum model and nutrient spiraling concept (e.g., Newbold et al., 1981), but river network characteristics have now been found to explain fish (Jaeger et al., 2014), macroinvertebrate (Clarke et al., 2008) and algal (Liu et al., 2013) community characteristics.

Within the network model, the critical components are the different river reaches while the critical connection is the longitudinal connection. Within reach outcomes would translate to the basin scale through either unique characteristics of particular reaches or the influences that propagate to other components through the longitudinal connection.

If this model is used, assessment at basin scale focuses on the critical components of the system (upland and lowland sections) and the exchanges between them.

\section{River basins as dynamic patch mosaics}

Basins are comprised of a patch mosaic (McCluney et al., 2014) in which patch composition, size, distribution and interactions drive basin structure and function. The patch mosaic conceptualization has three significant benefits. It improves integration of terrestrial and aquatic systems and supports examination of how relationships between patches vary through time. Consideration of patch dynamics also provides additional perspectives on heterogeneity within a basin. Third, the patch mosaic provides a basis for consideration of the role of disturbance in river basins through effects on mosaic composition, distribution and interactions.

Within the patch mosaic, the critical patches may include plums or river reaches described in the plum pudding and river network models but will include other components believed to interact with the river system at the basin scale. The critical connection will vary depending on the type of patch. Within patch outcomes would translate to the basin scale through either unique characteristics of particular patches (e.g., supporting an endangered species) or an outcome that propagates to other patches in the mosaic (e.g., patch acts as a source of recruits).

Adoption of a patch dynamic mosaic requires that the critical components are identified and assessed which may require a significant increase in information although this will be influenced by the scale, and the definition of patches.

\section{Process models}

Process models describe key ecological processes (e.g., primary productivity, dispersal, recruitment) that sustain the basin's character (composition, structure and function). While some process models can be derived from broad scale data (e.g., remotely sensed), many require small-scale information that then needs to be scaled up to the basin scale. The advantage of process models is that they are likely to be more sensitive to environmental change and changes in process are likely to precede basin scale compositional or structural changes.

Components within a process model will include the patch types that support the process and associated connections among them. Process changes will become significant at the basin scale if a process is unique to a patch (patch is a breeding site for a rare fish), if the process changes in a large number of patches across the basin (e.g., primary production) or the process outputs propagate across the basin (e.g., dispersal).

Development and application of a process model requires that process information and, where necessary, the information required to scale it up to the basin also be generated. Once again, this is likely to require a significant increase in the amount of information needed.

components: an inventory of their type and measures of their abundance and rates of change over different time intervals. We regularly do this at large-scales for climatic variables (e.g., mean annual temperature, total annual rainfall, etc.) and socioeconomic variables (e.g., total human population, number of settlements, $\%$ area irrigated) but may be less comfortable with, or less equipped to calculate, similarly scaled-up metrics for many ecological attributes beyond simple counts (e.g., number of Ramsar wetlands). Recent decades, however, have seen progress in determining basin-scale measures of some physical and biogeochemical processes, such as annual water balance, total sediment yields (e.g., De Rose et al., 2003) and total nutrient loads (e.g., de Vente and Poesen, 2005). Improved mapping technologies (i.e., remote sensing and GIS) have also facilitated better determination of topologic features at basinscales including number of wetlands, inundated area, total stream length, distribution of stream morphological types (Brierley and Fryirs, 2016), persistence of permanent water (Bunn et al., 
2006), and density of stream confluences (Benda et al., 2004). Biodiversity characteristics can similarly be described for a basin as a whole, i.e., numbers of species, composition, functional diversity etc. Describing river basins as a single unit and its associated inventory of characteristics provides a basis for the development of a black box conceptualization (Panel 1) to support management. The black box conceptualization makes no assumptions about whether the basin is a system or an aggregation. In terms of setting objectives for and evaluating environmental flows, a black box model makes no assumptions about the system and would be appropriate in situations where either very little is known, or where environmental flow management is undertaken at the scale of catchments within the Basin, and the focus was evaluating effectiveness across the Basin.

More elaborate descriptors use knowledge of both the presence of ecological components and some, albeit limited, knowledge of species' distributions. For example, in the process to get a wetland Ramsar listed, the nomination needs to provide information against 9 criteria concerning the role of the wetland in representing or supporting biodiversity in the region and the conservation status of dependent biota (Ramsar, 2016, page 45). If managers have undertaken a review of the basin's environmental assets then the basin description can include descriptions of these assets. In contrast to the "black box" model that describes the basin as a single entity, this information enables the basin to be conceptualized as a unit containing a limited number of high value assets; the plum pudding model (Panel 1). The plum pudding conceptualization still makes no assumptions about whether the basin is a system or an aggregation, but does provide a focus for delivery of environmental flows within the basin and their evaluation.

Beyond whole of basin characteristics, there are conceptualization of river basins that account for their internal structure and function. The Riverine Ecosystem Synthesis (RES) described rivers as being comprised of a series of Functional Process Zones (FPZ) (Thorp et al., 2006; McCluney et al., 2014) and a number of classification systems for rivers (Kasprak et al., 2016) and wetlands (Pressey and Adam, 1995; Brooks, 2017) are now available. At a finer scale we also have information on the structure of specific wetlands (Swirepik et al., 2016) or habitats that support particular taxa (e.g., Young et al., 2011) that may be key ecological assets at a basin-scale. The spatial organization of such ecological constituents (e.g., species' distributions) can differ considerably between basins that possess otherwise comparable compositional attributes (e.g., the same species pool). The degree of spatial heterogeneity of ecological attributes at a basin scale may be particularly important, not least because riverine macrosystems often display high cross-scale resistance to disturbances as a result of temporal asynchrony between their constituent patches (McCluney et al., 2014). Basins with greater spatial heterogeneity might therefore be expected to exhibit greater resilience to certain disturbances than more ecologically homogenous basins (Stendera et al., 2012). The temporal asynchrony introduces an important temporal dimension to the delivery of environmental flows given that the specific sites important for sustaining populations are likely to vary through time. The Commonwealth Environmental Water Office
(CEWO) have already recognized this in the MDB and classify years according to water availability with refuges prioritized during very dry years and lateral connectivity prioritized during very wet years (CEWO, 2013, p16). It is, however, possible that this temporal variation may operate at both longer and shorter time scales.

From a functional perspective, patterns of internal connectivity (longitudinal, lateral, and vertical) are significant, including floodplains and their catchments, and where known should be included in descriptions of river basin character (Nislow et al., 2010; Crook et al., 2015). Connectivity governs the movement of materials, energy and biota within and between basins and is recognized as fundamental to basin-scale ecological function and resilience (Pringle, 2003). Different organisms, life history stages and processes, however, operate across different scales such that critical patterns of connectivity vary depending on the species or process being considered (Fuller et al., 2015). Some species, for example, are broad-ranging across basins creating opportunities for the existence of strong links between distant regions whilst others are more restricted (Poiani, 2006). The spatial arrangement of different ecosystems and their associated habitats within basins will affect connectivity and (e.g., proximity of feeding and breeding habitats) is therefore of basinscale ecological importance. Information on patterns of internal connectivity enable development of a network conceptualization. The network describes the interactions between parts of the basin mediated by the patterns of connectivity. The precise nature of the network model will depend on the biota being considered with linear networks being appropriate for macroinvertebrates (Clarke et al., 2008) and fish (Lois and Cowley, 2017; Radinger et al., 2017), while a dispersed network may be more appropriate for waterbirds (Kingsford et al., 2010; Pedler et al., 2014) and their passengers (Reynolds et al., 2015).

Access to information on the distribution and abundance of ecosystem types within a basin enables development of a patch dynamics conceptualization and associated description (van Coller et al., 2000; Landis, 2003; Talley, 2007). While a patch dynamics model does not make any assumptions about whether or how the patches interact, it does provide an important source of information on changes in the relative abundance of patches and the landscape mosaic in which they are located. This information can then inform development of hypotheses around issues of connectivity and interdependence. A patch dynamic model may be of value when considering the management of environmental flows under climate change in which the system will need to adapt but continue to sustain nominated values (Girard et al., 2015).

Our limited knowledge of many species distributions and interactions in freshwater ecosystems often precludes the estimation of more process-based biological measures, e.g., patterns of dispersal, recruitment etc. Remote sensing techniques, however, increasingly enable a degree of quantification of certain biological processes (e.g., primary production) and ecosystem condition (e.g., vegetation greenness) at basin scales (Dornhofer and Oppelt, 2016). More elaborate descriptors depend on knowledge of both the presence of ecological components and the interactions among them and may include measures such 
as biomass production or carrying capacity e.g., of fish; (Ziv et al., 2012). River basins can also be characterized with respect to their overall ecological interactions with other systems at continental or global scales. Examples include a basin's role in sustaining migratory species or whether it is a sink or source of organisms (Heffernan et al., 2014). Development of a processbased conceptualization remains a significant challenge due to measurement difficulties, high degree of spatial and temporal heterogeneity and the range of scales over which they operate. With some being very localized but important at a Basin scale (e.g., sustaining habitat for a migratory bird), localized but propagating out to influence a significant area (e.g., waterbird recruitment) or being widespread across the basin (e.g., tree recruitment).

Ultimately, what is required are models that include the basin characteristics (structural, functional) that are relevant to the question being asked while achieving a balance between the simplistic and fatuous at one extreme and the complex but incomprehensible at the other. A "plum pudding" model, for example, may be appropriate for federal or regional authorities responsible for the management of national parks or Ramsar wetlands while decision-makers concerned with national or continental-scale comparisons of river basins may be best served by "black box" models. Model selection may also be informed by current ecological understanding of the basin-scale component or process being targeted by management. Managers concerned with basin-scale vegetation conservation, for example, might therefore opt for a patch dynamics model, as it most closely describes vegetation habitat (van Coller et al., 2000) while network models, describing habitat and connectivity, may better suit those managing fisheries (Crook et al., 2015; Eros, 2017).

\section{Basin-scale Effects of Environmental Watering}

The models described above will help formulate environmental flow objectives, but additional information is required to monitor and evaluate the anticipated contribution of smaller-scale environmental flows to achievement of basin-scale objectives (Kondolf et al., 2008). There are three conceptual pathways by which smaller-scale environmental flows can contribute to basinscale objectives. First, some localized outcomes of small-scale environmental flows may be of basin-scale significance simply due to the uniqueness of the values which they support, e.g., survival of an isolated population of an endangered species (Bino et al., 2018). Second, the cumulative effects of multiple watering interventions dispersed either spatially or through time (or both) can influence ecological character and condition at the basinscale including measures of presence/absence and totals/rates of constituent elements as well as their spatial arrangement and heterogeneity e.g., riparian vegetation (Shafroth et al., 2017; Cunningham et al., 2018). Finally, small-scale watering interventions can exert an influence on large-scale processes or basin-scale properties. For example, local watering may influence basin-scale patterns of connectivity, e.g., by bridging a gap in wetland "stepping stones" along a flyway for migrating bird species (Amezaga et al., 2002; Kingsford et al., 2010) or facilitating recolonization by species persisting in local refuges (Thiem et al., 2017). Similarly, the cumulative effects of multiple watering events will influence the spatial heterogeneity and juxtaposition of ecological patches within a basin therefore influencing portfolio effects and basin-scale resilience (McCluney et al., 2014).

Identification of a basin scale concept and flow-contribution concepts are an important input to the design of a monitoring program (Bernhardt et al., 2007; Wingard and Lorenz, 2014). Monitoring responses to environmental flows remains a challenge due to both knowledge gaps (McCoy et al., 2018) and the complex relationship between flow and ecological response (Summers et al., 2015) which can lead to variable responses (Souchon et al., 2008; Poff and Zimmerman, 2010). These challenges increase at larger scales due to the increased number of confounding variables that may influence or obscure environmental responses (Summers et al., 2015). Given the levels of uncertainty about the influence of flow regimes at the basin scale, applying our conceptual understanding to the design of effective monitoring and evaluation is necessary to support basinscale adaptive management (Convertino et al., 2013).

\section{Measurement and Monitoring}

There are numerous criteria for selecting indicators (Cairns et al., 1993; Dale and Beyler, 2001; Doren et al., 2009) and innumerable potential indicators that could be monitored (Jorgensen et al., 2013; Pander and Geist, 2013; McCoy et al., 2018). In the MDB example, selection of environmental indicators of environmental flow outcomes was influenced by this extensive literature on indicators (Donnelly et al., 2007; King et al., 2015), the management (Basin Plan) objectives and the objectives of the monitoring program (Gawne et al., 2013). Monitoring design was, therefore, based on a train of logic that started with the flow objective conceptualizations, which informed environmental flow planning which then informed the design of the monitoring program. As a consequence, any changes in the basin scale conceptualization would cascade down to influence the monitoring program.

The water requirement conceptualizations led to a monitoring program based on seven sites across the MDB that examine short ( $<12$ months) and long-term (1-5years) outcomes for hydrology vegetation (Stewardson and Guarino, 2018), inchannel metabolism and fish populations (Gawne et al., 2014). While some of the sites were extensive (e.g., Murrumbidgee site covers 750 river $\mathrm{km}$ ), the focus on sites without consideration of tele-connections increased two risks. The first, discussed earlier, is that both short-term responses and long-term legacies would be more, or less, likely to occur due to the influence of teleconnections. Including consideration of tele-connections may have allowed inclusion of additional data that would have helped explain some of the expected variation in response to flows through time and among sites (Poff and Zimmerman, 2010). Second, the design increases the risk that long-term legacies of environmental flows are not detected because they become manifest outside the monitored areas. For example, fish may move laterally or longitudinally to complete their life cycle (Eros, 2017) or vegetation may produce seeds that influence either downstream systems (Nilsson et al., 2010; Greet et al., 2011; 
Parolin et al., 2013) or systems subsequently visited by waterbirds (Figuerola and Green, 2002).

The general indicators used to monitor and evaluate Basin Plan environmental flows (vegetation, metabolism, fish) may not have been influenced by the conceptualization. It is likely, however, that the specific metrics (e.g., population characteristics), process indicators linking flow to general indicators and the sampling design would have been different. This suggests that the basin conceptualization will influence the selection of indicators. As an illustration we have taken the framework developed by Noss (1990) that classifies biodiversity indicators as compositional, structural, or functional and provided examples of basin-scale indicators relevant to each of the conceptual models (Table 1). As described in Table 1, a "black box" conceptualization suggests the selection of indicators concerning totals of compositional elements (e.g., species numbers) or rates of functional processes (e.g., biomass turnover). In contrast, a basin network model is more likely to monitor structural or functional measures concerning the arrangement and operation of network nodes and segments. This does not preclude the application of other criteria for the selection of indicators (e.g., diagnostic ability, feasibility or sensitivity Doren et al., 2009) but consideration of the conceptual model ensures that monitoring outputs enable evaluation of our understanding of the system which is an important part of adaptive management (Parrott and Quinn, 2016; Roberts et al., 2016).

The pathway by which indicator responses contribute to Basin scale objectives (Figure 1) was an important input to the design. Where small-scale effects have basin-scale significance due to their uniqueness, sampling is often constrained to areas directly influenced by management interventions. In contrast, if basin-scale outcomes are to be achieved through aggregated effects of multiple small-scale interventions, sampling will also need to quantify the proportion of the basin influenced by management interventions. Similarly, if basinscale outcomes are expected to occur via large-scale propagation of changes from a small area of intervention, then sampling will need to assess the entire basin or, using the appropriate conceptualization, monitor those areas in which outcomes are expected.

\section{Evaluating Ecological Significance at a Basin-scale}

In addition to selecting appropriate indicators to evaluate basin-scale outcomes of environmental watering, frameworks to assess measured indicators and their variation in time and space in relation to management objectives are also required. In many cases, decision-makers will want to know

TABLE 1 | Examples of the different types of compositional, structural, and functional indicators that would be relevant to each of the different conceptual models (adapted from Noss, 1990).

BASIN-SCALE INDICATORS

\begin{tabular}{|c|c|c|c|}
\hline \multirow[t]{2}{*}{ Conceptual models } & Compositional & Structural & Functional \\
\hline & $\begin{array}{l}\text { Indicators of the constituent parts of the } \\
\text { system }\end{array}$ & $\begin{array}{l}\text { Indicators of the ways that the constituent } \\
\text { parts are arranged within the system }\end{array}$ & $\begin{array}{l}\text { Indicators of processes that influence the } \\
\text { system's structure, composition, or condition }\end{array}$ \\
\hline \multirow[t]{3}{*}{ Black box } & Means, totals-e.g., species, habitats & & Inputs/outputs-e.g., nutrients \\
\hline & & & Rates of processes-e.g., decomposition \\
\hline & & & Retention of materials/biota-e.g., sediment \\
\hline \multirow[t]{2}{*}{ Plum pudding } & $\begin{array}{l}\text { Number of iconic sites-e.g., Ramsar } \\
\text { wetlands }\end{array}$ & Spatial arrangement of iconic sites & Disturbance processes \\
\hline & $\begin{array}{l}\text { Number of rare species Population size of } \\
\text { rare species }\end{array}$ & & Demographic processes of key species \\
\hline \multirow[t]{4}{*}{ Reticulated network } & Numbers of nodes & Identity, distribution, length of reaches & Movement of organisms \\
\hline & $\begin{array}{l}\text { Number and types of reach (functional } \\
\text { process zone) }\end{array}$ & Connectivity among reaches & Retention of material e.g., detritus \\
\hline & & Fragmentation e.g., Barriers & $\begin{array}{l}\text { Transformation of organisms e.g., herbivory, } \\
\text { predation }\end{array}$ \\
\hline & & & $\begin{array}{l}\text { Transformation of material e.g., } \\
\text { decomposition }\end{array}$ \\
\hline \multirow[t]{3}{*}{ Patch mosaic } & Identity, distribution, richness of patches & Heterogeneity & Patch persistence and turnover \\
\hline & Species minimal viable population size(s) & Fragmentation & Presence and distribution of refugia \\
\hline & Minimum extent of ecosystem type(s) & Juxtaposition of patches & Metapopulation dynamics \\
\hline \multirow[t]{5}{*}{ Process } & Species or patches that influence processes & $\begin{array}{l}\text { Distribution of energy flow processes in } \\
\text { space and time }\end{array}$ & Energy flow rates \\
\hline & Species or patches that influence system & Locations of sediment sources and sinks & Patch persistence and turn-over \\
\hline & response to disturbance & & Sediment and geomorphic processes \\
\hline & & & Nutrient fluxes \\
\hline & & & Contaminant fluxes \\
\hline
\end{tabular}




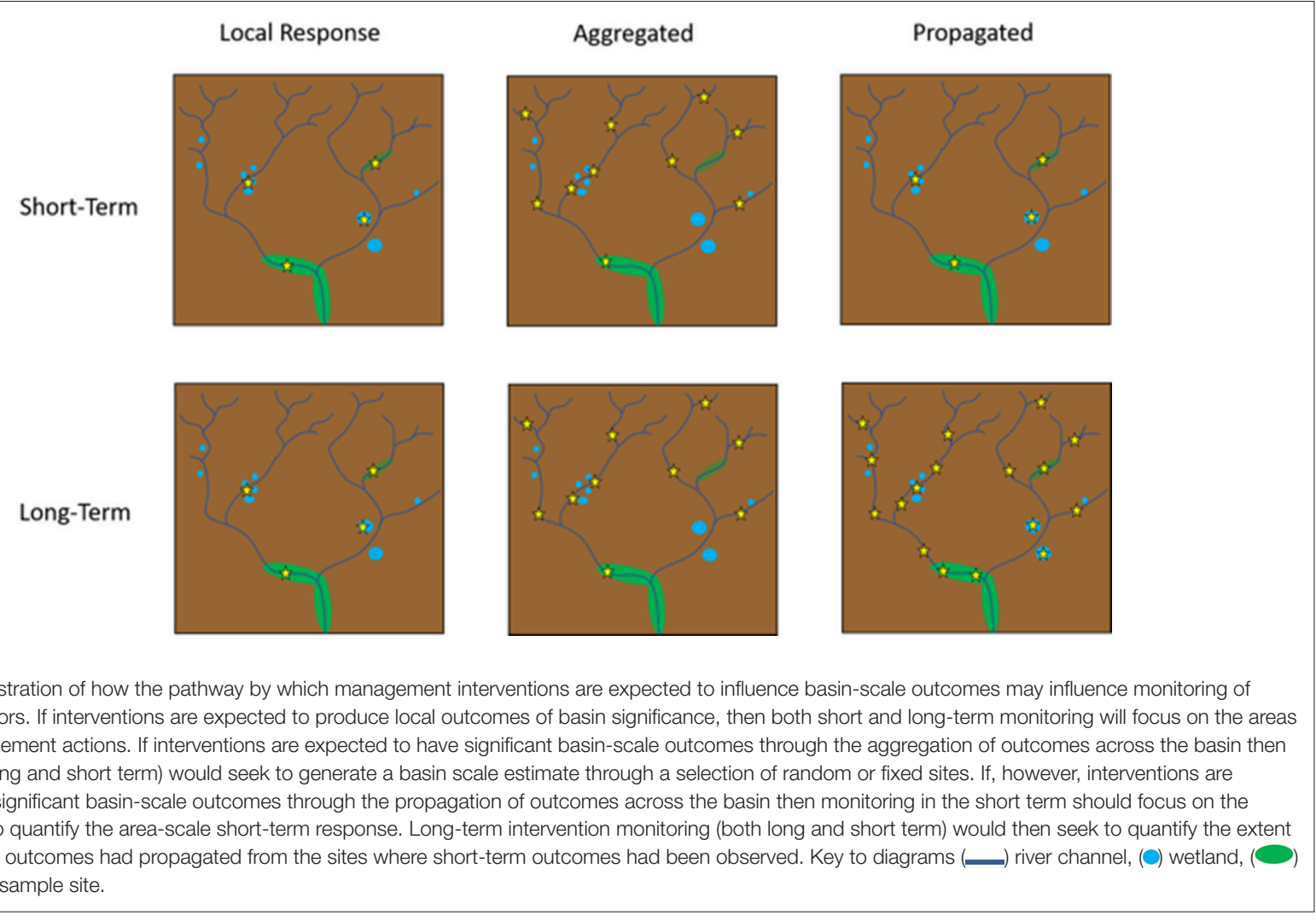

what changes are ecologically significant at a basin-scale. Most commonly, significant changes reported by ecological monitoring involve evaluation of indicators against targets which are usually defined in relation to socio-political values or the quantification of biological components or processes or some combination of both (Carwardine et al., 2009). Basin-scale objectives for environmental watering may include such socio-politically determined targets as the maintenance of the ecological character of all Ramsar wetlands or the conservation of endangered species within that basin. More ecologically informed targets, however, could be developed in relation to structural and functional indicators associated with network or patch mosaic models, e.g., the maintenance of particular levels of heterogeneity or connectivity between habitat types. Indicators arising from "black box" basin models may also be used to develop targets such as keeping catchment sediment loads below certain threshold values. In all cases, however, the particular significance level assigned to indicators to specify targets will necessarily be subjective and based on what is deemed to be an acceptable (or unacceptable) level of change (e.g., nil loss, no more than 30\% change etc.).

Non-target based, but quantitative approaches to evaluating the significance of conservation actions have also been proposed. Linear and curved utility functions, for example, enable managers to assess the benefits of incremental increases in the application of conservation measures (Davis et al., 2006; Wilson et al., 2007). Although such approaches can be criticized for failing to provide managers with clearly assessable goals (e.g., Carwardine et al., 2009), non-target based approaches can also promote a more nuanced approach to decision-making involving trade-offs rather than absolutes (Capon and Capon, 2017). With regards to evaluating the basin-scale significance of environmental flows, for instance, utility functions could enable managers to consider trade-offs between predicted benefits and the amount of water delivered.

\section{Multiple Conceptual Models}

An interesting point to emerge from the development of long-term intervention monitoring in the MDB was that the integrated concepts that underpinned environmental water planning (flow changes, ecosystem water requirements, and species water requirements) were subsequently disaggregated to support objective setting and evaluation processes. This pragmatic application of conceptual knowledge arose from the need for strong supporting science and the development of an ecosystem scale conceptualization. This raises the question of whether development of a basin scale conceptualization, as per Poff and Matthews (2013) would have improved outcomes. A basin scale model may have focused attention on the basin scale rather than on the water requirements of individual ecosystems with unknown consequences for those ecosystems. A unified basin-scale model may also not have supported the application of model components to environmental flow objective setting, monitoring or evaluation. This is not to say that monitoring and evaluation is not revealing new basin-scale insights, rather 
that if a basin scale model were to be developed, that the approach adopted in the MDB, has a number of benefits. Specifically, that examining the system from several different perspectives provides a strong foundation for an environmental flows program and carries with it the opportunity to pick, choose, integrate and adapt the relevant perspectives for the various activities required to plan, deliver and evaluate those flows (Hart, 2016).

The development and application of multiple models provided a means of dealing with complexity and through comparison of different models identifies cross-scale interactions and trade-offs. Here we have emphasized the spatial component, but it is likely that the variety of environmental flow types and their legacies will also require individual conceptualizations which underscores the need for multiple models.

Many large-scale restoration programs utilize multiple models. In some instances, the different models focus on different threats (Nõges et al., 2016; Davis et al., 2017). In other systems multiple models are developed to forecast responses by different biotic groups (Sklar et al., 2001; Lovich and Melis, 2007). In many ways these approaches are similar to the approach taken in the MDB in that their focus is ecosystems and species and while there may be a basin-scale conceptualization (Perry, 2004) the development of multiple basin scale conceptualizations appears unusual. The experience in the MDB suggests that the development of multiple conceptual models at the basin scale provides an improved foundation for the adaptive management of basin-scale management of environmental flows.

\section{Challenges and Future Directions \\ Current Limitations}

There are two broad limitations. The first, as noted earlier are knowledge gaps in macro-system ecology (McCain, 2013; McCluney et al., 2014). There have been significant improvements in our understanding of river basins that mean we can now describe the key ecological constituents, and some of the critical connections and processes that sustain values such as diversity and the provision of ecosystem services (Trabucchi et al., 2012; Boulton et al., 2016; Flotemersch et al., 2016). While managers can be confident in the identification of key constituents, there has been little examination of the number, area or distribution of these constituents required to sustain values, due at least in part to ongoing questions about the effectiveness of protected areas for freshwater systems (Chessman, 2013; Hermoso et al., 2016). Similarly, the importance of longitudinal and lateral patterns of connectivity is now recognized, but there is more uncertainty about biotic connections including the movements of some species of fish (Baumgartner et al., 2014; Stoffels et al., 2014, 2016) or hydrochory in sustaining plant communities (Nilsson et al., 2010; Parolin et al., 2013). It is likely that this knowledge will accumulate slowly as many macro-scale changes are likely to occur over extended periods of time from decades (e.g., population declines) to centuries, e.g., shifts in channel morphology (Jiang et al., 2018). In many instances macroscale responses to anthropogenic disturbances take time to become manifest (Petts and Gurnell, 2005; Mac Nally et al.,
2011) and we have limited capacity to predict outcomes (Stendera et al., 2012; Savenije et al., 2014). We have a much better understanding of smaller-scale, faster acting responses to change, however, there are challenges associated with scaling these up to a basin scale due to the complex nature of these systems (de Vente and Poesen, 2005; Thorp, 2014).

The second limitation is the integration of macro-scale considerations into basin-scale integrated water management. At the scale of an individual ecosystem, it is feasible in some instances to isolate or insulate the system from some major pressures. This can be achieved by creating protected areas or by focusing limited resources on a small number of systems. For example, the Living Murray program in south-eastern Australia allocates environmental flows to five iconic wetland sites along its $2,500 \mathrm{~km}$ length in order to ensure outcomes are achieved (MDBA, 2016). The limitation of this approach is that it is not dealing with the stress at the scale at which it occurs, so that interconnectedness among ecosystems within a basin can constrain rehabilitation (Dudgeon et al., 2006).

There are also numerous technical and logistical challenges associated with the adaptive management of environmental water at the basin scale. Limited information on basin characteristics and their response to change affects development of an appropriate reference or benchmark for setting objectives and evaluating management interventions. Managing at the basin scale also requires engagement of a greater diversity of people and institutions, which brings a new suite of challenges (Margerum and Whitall, 2004).

\section{Opportunities}

Despite the major challenges identified above, CEWO is already exploring opportunities to incorporate macro-scale ecology into the management of environmental flows. For example, coordinated delivery of flows to multiple wetlands (CEWO, 2017) and coordinate releases from several rivers to support native fish populations (CEWO, 2018). These changes in the delivery of environmental water represent the completion of the adaptive management cycle at the operational level. The intervention monitoring is also in the process of being reviewed and there will be opportunities to adapt the monitoring design to include consideration of these types of water actions and their associated large scale, long-term responses. The Basin Plan is reviewed every five years with a major review to be undertaken in 2024 (Australian Government, 2012). This will be an opportunity to apply the knowledge generated from the allocation of water across the Basin to the conceptualization that underpins the management, monitoring and evaluation of environmental flows. In preparation for the review there will be opportunities to utilize the data gathered by the intervention and condition monitoring to start to identify some of the cross-scale interactions and connections that influence macrosystem responses to environmental flows (Thorp, 2014). This process could apply some of the lessons learnt from other large-scale, long-term monitoring programs, such as the U.S. wadeable streams assessment (Paulsen et al., 2008) or European water directive 
monitoring (Kaika, 2003; Hering et al., 2010) to undertake comparisons among river basins. The outputs of this analysis would help reduce uncertainty around the water required to sustain environmental values across the Basin and support the successful implementation of adaptive management at the basin scale in accordance with the Basin Plan (Australian Government, 2007, 2012).

The identification of macro-scale influences of flow regimes is likely to create further technical challenges in terms of the monitoring and evaluation of environmental flows at multiple scales. There are, however, advances in our capacity to monitor responses to environmental flows, including remote sensing and GIS modeling that increase managers' capacity to generate basin-scale data. For example, remote sensing can now support river morphology (Belletti et al., 2017), organic matter input (Hoffmann et al., 2016) and individual tree condition (Shendryk et al., 2016) assessments. Improvements in monitoring technology are also likely to improve opportunities for extensive on ground monitoring through increased community participation, telemetry and techniques such as environmental DNA. There are similar advances in our capacity to manage the large data sets created by these new monitoring approaches (Koo et al., 2015; Etzion and Aragon-Correa, 2016). The existence of large complex data sets also provides opportunities for novel analytical techniques to extract more value from the data collected (Phan et al., 2016).

\section{CONCLUSIONS}

Environmental flow management at the basin scale currently represents a significant challenge, due to river basin's the complexity associated with achieving social, economic, and environmental objectives, knowledge gaps, and technical challenges in generating information at the basin scale. Basinscale management is, however, important if environmental values are to be sustained at both the basin scale but also within high value rivers, wetlands and rivers. Inclusion of basin scale considerations is also likely to create opportunities to better understand the relationship between basin condition and the delivery of ecosystem services (Capon and Bunn, 2015). Given its importance and the limited resources available, it is important that the principles of adaptive management are applied, and that available knowledge is effectively applied to support the planning, monitoring and evaluation of environmental flows. Within this context the development of a series of conceptual models focused on individual objectives that can be integrated or adapted to suit the different decisions required at different steps in the adaptive management process will facilitate application of knowledge, provide a means of dealing with complexity and a

\section{REFERENCES}

Amezaga, J. M., Santamaria, L., and Green, A. J. (2002). Biotic wetland connectivity - supporting a new approach for wetland policy. Acta Oecol. Int. J. Ecol. 23, 213-222. doi: 10.1016/S1146-609X(02)01152-9 platform for identifying synergies, trade-offs and risks associated with proposed management actions.

\section{AUTHOR CONTRIBUTIONS}

BG, Project leader of the LTIM project. Undertook major revision of first draft and responses to subsequent feedback from collaborating authors. SC, Member of the leadership team that developed LTIM Authored first draft. JH, Member of the leadership team that developed LTIM. Worked with BG on finalization of paper. SB, Member of the leadership team that developed LTIM. Worked with BG on finalization of paper. CC, Member of the leadership team that developed LTIM. Provided feedback on successive drafts until she went on maternity leave. MS, Member of the leadership team that developed LTIM. Provided feedback on draft manuscript. MG, Member of the leadership team that developed LTIM. Provided feedback on draft manuscript. RS, Member of the leadership team that developed LTIM. Provided feedback on draft manuscript. FG, Member of the leadership team that developed LTIM. Provided feedback on successive drafts of the manuscript. PE, Member of the leadership team that developed LTIM. Provided feedback on successive drafts of the manuscript.

\section{FUNDING}

Funding was provided by each authors' employing institution. The manuscript is based on work undertaken for and funded by the Australian Commonwealth Environmental Waterholder, however, the work required to complete this manuscript was not a contracted output of the project.

\section{ACKNOWLEDGMENTS}

The content of this paper arose from the challenges associated with the development of the Commonwealth Environmental Waterholder's (CEWH) Long-Term Intervention Monitoring (LTIM) program. As a result, the authors would like to acknowledge the contribution of the Monitoring and Evaluation Team at the office of the Commonwealth Environmental Waterholder. Tim Wyndham, Erin Murrihy, and Sam Roseby guided the program's key formative stages, and the subsequent contributions by Paul Marsh and Andy Lowes. We would also like to thank the many people involved in the LTIM project, in particular, the leaders of the Area evaluation teams; Fiona Dyer, Paul Frazier, Qifeng Ye, Darren Ryder, Skye Wassens, Robyn Watts and Angus Webb. We would also like to acknowledge the contribution of two reviewers for their constructive feedback on the manuscript. 
Baumgartner, L., Zampatti, B., Jones, M., Stuart, I., and Mallen-Cooper, M. (2014). Fish passage in the Murray-Darling Basin, Australia: not just an upstream battle. Ecol. Manage. Restor. 15, 28-39. doi: 10.1111/emr.12093

Belletti, B., Rinaldi, M., Bussettini, M., Comiti, F., Gurnell, A. M., Mao, L., et al. (2017). Characterising physical habitats and fluvial hydromorphology: a new system for the survey and classification of river geomorphic units. Geomorphology 283, 143-157. doi: 10.1016/j.geomorph.2017.01.032

Benda, L., Andras, K., Miller, D., and Bigelow, P. (2004). Confluence effects in rivers: interactions of basin scale, network geometry, and disturbance regimes. Water Resour. Res. 40:W05402. doi: 10.1029/2003WR002583

Bernhardt, E. S., Sudduth, E. B., Palmer, M. A., Allan, J. D., Meyer, J. L., Alexander, G., et al. (2007). Restoring rivers one reach at a time: results from a survey of US river restoration practitioners. Restor. Ecol. 15, 482-493. doi: 10.1111/j.1526-100X.2007.00244.X

Bino, G., Wassens, S., Kingsford, R. T., Thomas, R. F., and Spencer, J. (2018). Floodplain ecosystem dynamics under extreme dry and wet phases in semi-arid Australia. Freshw. Biol. 63, 224-241. doi: 10.1111/fwb.13056

Boulton, A. J., Ekebom, J., and Gislason, G. M. (2016). Integrating ecosystem services into conservation strategies for freshwater and marine habitats: a review. Aquat. Conserv. Mar. Freshw. Ecosyst. 26, 963-985. doi: $10.1002 /$ aqc. 2703

Brierley, G. J., and Fryirs, K. A. (2016). The use of evolutionary trajectories to guide "moving targets' in the management of river futures. River Res. Appl. 32, 823-835. doi: 10.1002/rra.2930

Brooks, S. (2017). Classification of Aquatic ecosystems in the Murray-Darling Basin: 2017 Update. Canberra, ACT: Murray-Darling Basin Authority and Commonwealth Environmental Water Office.

Bunn, S. E., Thoms, M. C., Hamilton, S. K., and Capon, S. J. (2006). Flow variability in dryland rivers: boom, bust and the bits in between. River Res. Appl. 22, 179-186. doi: 10.1002/rra.904

Cairns, J., McCormick, P. V., and Niederlehner, B. R. (1993). A proposed framework for developing indicators of ecosystem health. Hydrobiologia 263, 1-44. doi: 10.1007/BF00006084

Capon, S. (2014). "Adapting water resource management to drought and water scarcity in Australia's Murray-Darling Basin," in Adaptation to Climate Change Through Water Resources Management: Capacity, Equity and Sustainability (London: Routledge publishers), 110.

Capon, S., and Bunn, S. E. (2015). "Assessing climate change risks and prioritising adaptation options using a water ecosystem services-based approach," in Ecosystem Services: A Global Perspective, eds J. Martin-Ortega, R. C. Ferrier, I. J. Gordon, and S. Khan Cambridge: Cambridge University Press), 17-25.

Capon, S. J., and Capon, T. R. (2017). An impossible prescription: why science cannot determine environmental water requirements for a healthy murraydarling basin. Water Econ. Policy 3:17. doi: 10.1142/S2382624X16500375

Carwardine, J., Klein, C. J., Wilson, K. A., Pressey, R. L., and Possingham, H. P. (2009). Hitting the target and missing the point: targetbased conservation planning in context. Conserv. Lett. 2, 3-10. doi: 10.1111/j.1755-263X.2008.00042.x

CEWO (2013). Commonwealth Environmental Water - Monitoring, Evaluation, Reporting and Improvement Framework. Canberra, ACT: Commonwealth Environmental Water Office.

CEWO (2017). Environmental Watering in the Mid-Murray Catchment in Previous Years. Canberra, ACT: Australian Commonwealth Government. Available online at: http://www.environment.gov.au/water/cewo/catchment/ mid-murray/history\#murray-16 (Accessed May 24, 2018).

CEWO (2018). Northern Connectivity Event Update 25 May 2018. Canberra ACT: Australian Commonwealth Government. Available online at: http://www. environment.gov.au/water/cewo/northern-rivers (Accessed May 24, 2018).

Chessman, B. C. (2013). Do protected areas benefit freshwater species? A broadscale assessment for fish in australia's murray-darling basin. J. Appl. Ecol. 50, 969-976. doi: 10.1111/1365-2664.12104

Clarke, A., Mac Nally, R., Bond, N., and Lake, P. S. (2008). Macroinvertebrate diversity in headwater streams: a review. Freshw. Biol. 53, 1707-1721. doi: 10.1111/j.1365-2427.2008.02041.x

Convertino, M., Baker, K. M., Vogel, J. T., Lu, C., Suedel, B., and Linkov, I. (2013). Multi-criteria decision analysis to select metrics for design and monitoring of sustainable ecosystem restorations. Ecol. Indic. 26, 76-86. doi: $10.1016 /$ j.ecolind.2012.10.005
Crabb, P. (1997). Murray-Darling Basin Resources. Canberra ACT: CSIRO Publishing.

Crook, D. A., Lowe, W. H., Allendorf, F. W., Eros, T., Finn, D. S., Gillanders, B. M., et al. (2015). Human effects on ecological connectivity in aquatic ecosystems: integrating scientific approaches to support management and mitigation. Sci. Total Environ. 534, 52-64. doi: 10.1016/j.scitotenv.2015.04.034

Cunningham, S. C., Griffioen, P., White, M. D., and Mac Nally, R. (2018). Assessment of ecosystems: a system for rigorous and rapid mapping of floodplain forest condition for Australia's most important river. Land Degrad. Dev. 29, 127-137. doi: 10.1002/ldr.2845

Dale, V., and Beyler, S. (2001). Challenges in the development and use of ecological indicators. Ecol. Indic. 1, 3-10. doi: 10.1016/S1470-160X(01)00003-6

Davies, P., Harris, J., Hillman, T. J., and Walker, K. F. (2008). SRA Report 1: A Report on the Ecological Health of Rivers in the Murray-Darling Basin, 20042007. Prepared by the Independent Sustainable Rivers Audit Group for the Murray-Darling Basin Commission (Canberra, ACT: Murray-Darling Basin Commission).

Davis, A. M., Pearson, R. G., Brodie, J. E., and Butler, B. (2017). Review and conceptual models of agricultural impacts and water quality in waterways of the Great Barrier Reef catchment area. Mar. Freshw. Res. 68, 1-19. doi: 10.1071/MF15301

Davis, F. W., Costello, C., and Stoms, D. (2006). Efficient conservation in a utilitymaximization framework. Ecol. Soc. 11:33. doi: 10.5751/ES-01591-110133

De Rose, R., Prosser, I., Weisse., M, and Hughes, A. (2003). Patterns of Erosion and Sediment and Nutrient Transport in the Murray-Darling Basin. Canberra, ACT: CSIRO Land and Water.

de Vente, J., and Poesen, J. (2005). Predicting soil erosion and sediment yield at the basin scale: scale issues and semi-quantitative models. Earth Sci. Rev. 71, 95-125. doi: 10.1016/j.earscirev.2005.02.002

Dodrill, M. J., Yackulic, C. B., Gerig, B., Pine, W. E., Korman, J., and Finch, C. (2015). Do management actions to restore rare habitat benefit native fish conservation? Distribution of juvenile native fish among shoreline habitats of the colorado river. River Res. Appl. 31, 1203-1217. doi: 10.1002/rra.2842

Donnelly, A., Jones, M., O’Mahony, T., and Byrne, G. (2007). Selecting environmental indicator for use in strategic environmental assessment. Environ. Impact Assess. Rev. 27, 161-175. doi: 10.1016/j.eiar.2006.10.006

Doren, R. F., Trexler, J. C., Gottlieb, A. D., and Harwell, M. C. (2009). Ecological indicators for system-wide assessment of the greater everglades ecosystem restoration program. Ecol. Indic. 9, S2-S16. doi: 10.1016/j.ecolind.2008.08.009

Dorfman, E., and Kingsford, R. (2001). Scale-dependent patterns of abundance and habitat use by cormorants in arid Australia and the importance of nomadism. J. Arid Environ. 49, 677-694. doi: 10.1006/jare.2001.0825

Dornhofer, K., and Oppelt, N. (2016). Remote sensing for lake research and monitoring - recent advances. Ecol. Indic. 64, 105-122. doi: 10.1016/j.ecolind.2015.12.009

Dudgeon, D., Arthington, A. H., Gessner, M. O., Kawabata, Z. I., Knowler, D. J., Lévêque, C., et al. (2006). Freshwater biodiversity: importance, threats, status and conservation challenges. Biol. Rev. 81, 163-182. doi: 10.1017/S1464793105006950

Eros, T. (2017). Scaling fish metacommunities in stream networks: synthesis and future research avenues. Commun. Ecol. 18, 72-86. doi: 10.1556/168.2017.18.1.9

Etzion, D., and Aragon-Correa, J. A. (2016). Big data, management, and sustainability: strategic opportunities ahead. Organ. Environ. 29, 147-155. doi: $10.1177 / 1086026616650437$

Falkenmark, M., and Folke, C. (2002). The ethics of socio-ecohydrological catchment management: towards hydrosolidarity. Hydrol. Earth Syst. Sci. 6, 1-9. doi: 10.5194/hess-6-1-2002

Fausch, K. D., Torgersen, C. E., Baxter, C. V., and Li, H. W. (2002). Landscapes to riverscapes: Bridging the gap between research and conservation of stream fishes. Bioscience 52, 483-498. doi: 10.1641/0006-3568(2002)052[0483:Ltrbtg]2.0.Co;2

Figuerola, J., and Green, A. J. (2002). Dispersal of aquatic organisms by waterbirds: a review of past research and priorities for future studies. Freshw. Biol. 47, 483-494. doi: 10.1046/j.1365-2427.2002.00829.x

Flotemersch, J. E., Leibowitz, S. G., Hill, R. A., Stoddard, J. L., Thoms, M. C., and Tharme, R. E. (2016). A Watershed Integrity definition and assessment approach to support strategic management of watersheds. River Res. Appl. 32, 1654-1671. doi: 10.1002/rra.2978 
Freitag, S., Biggs, H., and Breen, C. (2014). The spread and maturation of strategic adaptive management within and beyond South African national parks. Ecol. Soc. 19:25. doi: 10.5751/ES-06338-190325

Friedman, J. M., and Lee, V. J. (2002). Extreme floods, channel change, and riparian forests along ephemeral streams. Ecol. Monogr. 72, 409-425.

Frith, H. (1957). Breeding and movements of wild ducks in inland New South Wales. CSIRO Wildlife Res. 2, 19-31. doi: 10.1071/CWR9570019

Frith, H. (1963). Movements and mortality rates of the black duck and grey teal in south-eastern Australia. CSIRO Wildlife Res. 8, 119-131. doi: 10.1071/CWR9630119

Fuller, M. R., Doyle, M. W., and Strayer, D. L. (2015). "Causes and consequences of habitat fragmentation in river networks," in Year in Ecology and Conservation Biology, eds A. G. Power and R. S. Ostfeld (New York, NY: New York Academy of Sciences), 31-51.

Gaff, H., DeAngelis, D. L., Gross, L. J., Salinas, R., and Shorrosh, M. (2000). A dynamic landscape model for fish in the Everglades and its application to restoration. Ecol. Model. 127, 33-52. doi: 10.1016/S0304-3800(99)00202-1

Gawne, B., Brooks, S., Butcher, R., Cottingham, P., and Everingham, P., Hale, J. et al. (2013). Long Term Intervention Monitoring Logic and Rationale Document in Final Report Prepared for the Commonwealth Environmental Water Office. The Murray-Darling Freshwater Research Centre.

Gawne, B., Hale, J., Brooks, S., Campbell, C., Capon, S., Everingham, P., et al. (2016). 2014-15 Basin-scale Evaluation of Commonwealth Environmental Water - Synthesis Report in Final Report Prepared forthe Commonwealth Environmental Water Office." The Murray-Darling Freshwater Research Centre.

Gawne, B., Hale, J., Brooks, S., Campbell, C., Capon, S., Everingham, P., et al. (2017). "2015-16 Basin-Scale Evaluation of Commonwealth Environmental Water - Synthesis Report in Final report prepared for the Commonwealth Environmental Water Office." The Murray-Darling Freshwater Research Centre.

Gawne, B., Roots, J., Hale, J., and Stewardson, M. (2014). Commonwealth Environmental Water Office Long- Term Intervention Monitoring Project: Basin Evaluation Plan. Commonwealth Environmental Water Office.

Girard, C., Pulido-Velazquez, M., Rinaudo, J-D., Page, C., and Caballero, Y. (2015). Integrating top-down and bottom-up approaches to design global change adaptation at the river basin scale. Glob. Environ. Change Hum. Policy Dimens. 34, 132-146. doi: 10.1016/j.gloenvcha.2015.07.002

Greet, J., Webb, J. A., and Downes, B. J. (2011). Flow variability maintains the structure and composition of in-channel riparian vegetation. Freshw. Biol. 56, 2514-2528. doi: 10.1111/j.1365-2427.2011.02676.x

Hart, B. T. (2016). The Australian murray-darling basin plan: challenges in its implementation (part 1). Int. J. Water Resour. Dev. 32, 819-834. doi: 10.1080/07900627.2015.1083847

Hart, B. T., and Davidson, D. (2017). "Case study 1-the murray-darling basin plan," in Decision Making in Water Resources Policy and Management: An Australian Perspective, eds B. T. Hart, and J. Doolan (London: Academic Press), 221-244.

Heffernan, J. B., Soranno, P. A., Angilletta, M. J. Jr., Buckley, L. B., Gruner, D. S., Keitt, T. H., et al. (2014). Macrosystems ecology: understanding ecological patterns and processes at continental scales. Front. Ecol. Environ. 12:17. doi: $10.1890 / 130017$

Hering, D., Borja, A., Carstensen, J., Carvalho, L., Elliott, M., Feld, C. K., et al. (2010). The European water framework directive at the age of 10: a critical review of the achievements with recommendations for the future. Sci. Total Environ. 408, 4007-4019. doi: 10.1016/j.scitotenv.2010.05.031

Hermoso, V., Abell, R., Linke, S., and Boon, P. (2016). The role of protected areas for freshwater biodiversity conservation: challenges and opportunities in a rapidly changing world. Aquat. Conserv. Mar. Freshwater Ecosyst. 26, 3-11. doi: 10.1002 aqc. 2681

Hoffmann, B., Feakins, S. J., Bookhagen, B., Olen, S. M., Adhikari, D. P., Mainali, J., et al. (2016). Climatic and geomorphic drivers of plant organic matter transport in the Arun River, E Nepal. Earth Planet. Sci. Lett. 452, 104-114. doi: 10.1016/j.epsl.2016.07.008

Horne, A. C., O’Donnell, E. L., Webb, J. A., Stewardson, M. J., Acreman, M., and Richter, B. (2017). “The environmental water management cycle," in Water for the Environment: From Policy and Science to Implementation and Management, eds A. C. Horne, J. A. Webb, M. J. Stewardson, B. Richter, and M. Acreman (London: Academic Press), 3-15.

Huntjens, P., Pahl-Wostl, C., and Grin, J. (2010). Climate change adaptation in European river basins. Reg. Environ. Change 10, 263-284. doi: 10.1007/s,10113009-0108-6

Jaeger, K. L., Olden, J. D., and Pelland, N. A. (2014). Climate change poised to threaten hydrologic connectivity and endemic fishes in dryland streams. Proc. Natl. Acad. Sci. U.S.A. 111, 13894-13899. doi: 10.1073/pnas.1320 890111

Jiang, C., Chen, S., Pan, S., Fan, Y., and Ji, H. (2018). Geomorphic evolution of the yellow river delta: quantification of basin-scale natural and anthropogenic impacts. CATENA 163, 361-377. doi: 10.1016/j.catena.2017.12.041

Jorgensen, S. E., Burkhard, B., and Muller, F. (2013). Twenty volumes of ecological indicators - An accounting short review. Ecol. Indic. 28, 4-9. doi: 10.1016/j.ecolind.2012.12.018

Kaika, M. (2003). The water framework directive: a new directive for a changing social, political and economic European framework. Eur. Plan. Stud. 11, 299-316. doi: 10.1080/09654310303640

Kasprak, A., Hough-Snee, N., Beechie, T., Bouwes, N., Brierley, G., Camp, R., et al. (2016). The blurred line between form and process: a comparison of stream channel classification frameworks. PLOS ONE 11:e0150293. doi: 10.1371/journal.pone.0150293

King, A. J., Gawne, B., Beesley, L., Koehn, J. D., Nielsen, D. L., and Price, A. (2015). Improving ecological response monitoring of environmental flows. Environ. Manage. 55, 991-1005. doi: 10.1007/s00267-015-0456-6

Kingsford, R. T., Bino, G., Porter, J. L., and Brandis, K. (2013). Waterbird Communities in the Murray-Darling Basin (1983-2012). Report to MurrayDarling Basin Authority (Sydney, NSW: Australian Wetlands, Rivers and Landscapes Centre, University of New South Wales).

Kingsford, R. T., Roshier, D. A., and Porter, J. L. (2010). Australian waterbirds time and space travellers in dynamic desert landscapes. Mar. Freshwater Res. 61, 875-884. doi: 10.1071/MF09088

Kondolf, G. M., Angermeier, P. L., Cummins, K., Dunne, T., Healey, M., Kimmerer, W., et al. (2008). Projecting Cumulative benefits of multiple river restoration projects: an example from the sacramento-san joaquin river system in California. Environ. Manage. 42, 933-945. doi: 10.1007/s00267-008-9162-y

Koo, D., Piratla, K., and Matthews, C. J. (2015). “Towards sustainable water supply: schematic development of big data collection using internet of things (IoT)," in Defining the Future of Sustainability and Resilience in Design, Engineering and Construction, eds W. O. Chong, J. Chang, K. Parrish, and U. Berardi (Amsterdam: Elsevier Science), 489-497.

Koster, W. M., Dawson, D. R., Liu, C., Moloney, P. D., Crook, D. A., and Thomson, J. R. (2017). Influence of streamflow on spawning-related movements of golden perch Macquaria ambigua in south-eastern Australia. J. Fish Biol. 90, 93-108. doi: $10.1111 /$ jfb. 13160

Landis, W. G. (2003). The frontiers in ecological risk assessment at expanding spatial and temporal scales. Hum. Ecol. Risk Assess. 9, 1415-1424. doi: 10.1080/10807030390250912

Lane, B. A., Sandoval-Solis, S., and Porse, E. C. (2015). Environmental flows in a human-dominated system: integrated water management strategies for the rio grande/bravo basin. River Res. Appl. 31, 1053-1065. doi: 10.1002/rra.2804

Laub, B. G., Jimenez, J., and Budy, P. (2015). Application of science-based restoration planning to a desert river system. Environ. Manage. 55, 1246-1261. doi: 10.1007/s00267-015-0481-5

Liu, J., Soininen, J., Han, B. P., and Declerck, S. A. J. (2013). Effects of connectivity, dispersal directionality and functional traits on the metacommunity structure of river benthic diatoms. J. Biogeogr. 40, 2238-2248. doi: 10.1111/jbi.12160

Lois, S., and Cowley, D. E. (2017). Conservation of interacting species in network-constrained environments. Divers. Distrib. 23, 1235-1245. doi: 10.1111/ddi.12623

Lovich, J., and Melis, T. S. (2007). The state of the colorado river ecosystem in grand canyon: lessons from 10 years of adaptive ecosystem management. Int. J. River Basin Manage.5, 207-221. doi: 10.1080/15715124.2007.963532

Mac Nally, R., Cunningham, S. C., Baker, P. J., Horner, G. J., and Thomson, J. R. (2011). Dynamics of murray-darling floodplain forests under multiple stressors: the past, present, and future of an Australian icon. Water Resour. Res. 47:W00G05. doi: 10.1029/2011WR010383 
Margerum, R. D., and Whitall, D. (2004). The challenges and implications of collaborative management on a river basin scale. J. Environ. Plan. Manage. 47, 409-429. doi: 10.1080/0964056042000216537

McCain, K. N. S. (2013). Moving large river ecology from past theories to future actions: a review. Rev. Fish. Sci. 21, 39-48. doi: 10.1080/10641262.2012. 753867

McCluney, K. E., Poff, N. L., Palmer, M. A., Thorp, J. H., Poole, G. C., Williams, B. S., et al. (2014). Riverine macrosystems ecology: sensitivity, resistance, and resilience of whole river basins with human alterations. Front. Ecol. Environ. 12:367. doi: 10.1890/120367

McCoy, A. L., Holmes, S. R., and Boisjolie, B. A. (2018). Flow restoration in the columbia river basin: an evaluation of a flow restoration accounting framework. Environ. Manage. 61, 506-519. doi: 10.1007/s00267-017-0926-0

MDBA (2011a). Delivering a Healthy Working Basin - About the Draft Basin Plan. Canberra, ACT: Murray-Darling Basin Authority.

MDBA (2011b). The Living Murray Story. One of Australia's Largest River Restoration Projects. Canberra, ACT: Murray-Darling Basin Authority.

MDBA (2016). The Living Murray Program. Canberra, ACT: Murray-Darling Basin Authority. Available online at: https://www.mdba.gov.au/managingwater/environmental-water/delivering-environmental-water/living-murrayprogram (Accessed January 16, 2018).

Nelson, A., and Dub, K. (2016). Channel response to an extreme flood and sediment pulse in a mixed bedrock and gravel-bed river. Earth Surf. Process. Landforms 41, 178-195. doi: 10.1002/esp.3843

Neto, S., Camkin, J., Fenemor, A., Tan, P. L., Baptista, J. M., Ribeiro, M., et al. (2018). OECD principles on water governance in practice: an assessment of existing frameworks in Europe, Asia-Pacific, Africa and South America. Water Int. 43, 60-89. doi: 10.1080/02508060.2018.1402650

Newbold, J. D., Elwood, J. W., Oneill, R. V., and Vanwinkle, W. (1981). Measuring nutrient spiralling in streams. Can. J. Fish. Aquat. Sci. 38, 860-863. doi: 10.1139/f81-114

Nilsson, C., Brown, R. L., Jansson, R., and Merritt, D. M. (2010). The role of hydrochory in structuring riparian and wetland vegetation. Biol. Rev. 85, 837-858. doi: 10.1111/j.1469-185X.2010.00129.x

Nislow, K. H., Marks, C. O., and Lutz, K. A. (2010). Aquatic Conservation Planning at a Landscape Scale. London: Springer.

Nõges, P., Argillier, C., Borja, Á., Garmendia, J. M., Hanganu, J., Kodeš, V., et al. (2016). Quantified biotic and abiotic responses to multiple stress in freshwater, marine and ground waters. Sci. Total Environ. 540, 43-52. doi: 10.1016/j.scitotenv.2015.06.045

Noss, R. F. (1990). Indicators for monitoring biodiversity - a hierarchical approach. Conserv. Biol. 4, 355-364. doi: 10.1111/j.1523-1739.1990.tb00309.x

OECD (2011). Water Governance in OECD Countries: A Multi-Level Approach. Paris: Organisation for Economic Co-operation and Development.

Olden, J. D., Konrad, C. P., Melis, T. S., Kennard, M. J., Freeman, M. C., Mims, M. C., et al. (2014). Are large-scale flow experiments informing the science and management of freshwater ecosystems? Front. Ecol. Environ. 12:76. doi: $10.1890 / 130076$

Palmer, M. A., Hondula, K. L., and Koch, B. J. (2014). Ecological restoration of streams and rivers: shifting strategies and shifting goals. Ann. Rev. Ecol. Evol. Syst. 45, 247-269. doi: 10.1146/annurev-ecolsys-120213-091935

Pander, J., and Geist, J. (2013). Ecological indicators for stream restoration success. Ecol. Indic. 30, 106-118. doi: 10.1016/j.ecolind.2013.01.039

Parolin, P., Wittmann, F., and Ferreira, L. V. (2013). Fruit and seed dispersal in amazonian floodplain trees - a review. Ecotropica 19, 15-32.

Parrott, L., and Quinn, N. (2016). A complex systems approach for multiobjective water quality regulation on managed wetland landscapes. Ecosphere 7:e01363. doi: $10.1002 /$ ecs 2.1363

Paulsen, S. G., Mayio, A., Peck, D. V., Stoddard, J. L., Tarquinio, E., Holdsworth, S. M., et al. (2008). Condition of stream ecosystems in the US: an overview of the first national assessment. J. North Am. Benthol. Soc. 27, 812-821. doi: 10.1899/08-098.1

Pedler, R. D., Ribot, R. F., and Bennett, A. T. (2014). Extreme nomadism in desert waterbirds: flights of the banded stilt. Biol. Lett. 10:20140547. doi: $10.1098 /$ rsbl.2014.0547

Perry, W. (2004). Elements of south florida's comprehensive everglades restoration plan. Ecotoxicology 13, 185-193. doi: 10.1023/B:ECTX.0000023564. $10311.4 \mathrm{a}$
Petts, G. E., and Gurnell, A. M. (2005). Dams and geomorphology: research progress and future directions. Geomorphology 71, 27-47. doi: 10.1016/j.geomorph.2004.02.015

Phan, T. D., Smart, J. C. R., Capon, S. J., Hadwen, W. L., and Sahin, O. (2016). Applications of bayesian belief networks in water resource management: a systematic review. Environ. Model. Softw. 85, 98-111. doi: 10.1016/j.envsoft.2016.08.006

Poff, N. L., and Matthews, J. H. (2013). Environmental flows in the Anthropocence: past progress and future prospects. Curr. Opin. Environ. Sustain. 5, 667-675. doi: 10.1016/j.cosust.2013.11.006

Poff, N. L., Tharme, R. E., and Arthington, A. H. (2017). "Evolution of environmental flows assessment science, principles, and methodologies," in Water for the Environment: From Policy and Science to Implementation and Management, eds A. C. Horne, J. A. Webb, M. J. Stewardson, B. Richter, and M. Acreman. (London: Academic Press), 203-228.

Poff, N. L., and Zimmerman, J. K. H. (2010). Ecological responses to altered flow regimes: a literature review to inform the science and management of environmental flows. Freshw. Biol. 55, 194-205. doi: 10.1111/j.1365-2427.2009.02272.x

Poiani, A. (2006). Effects of floods on distribution and reproduction of aquatic birds. Adv. Ecol. Res. 39, 63-83. doi: 10.1016/s0065-2504(06)39004-6

Porse, E. C., Sandoval-Solis, S., and Lane, B. A. (2015). Integrating environmental flows into multi-objective reservoir management for a transboundary, waterscarce river basin: rio Grande/Bravo. Water Resour. Manage. 29, 2471-2484. doi: 10.1007/s11269-015-0952-8

Pressey, R. L., and Adam, P. (1995). A review of wetland inventory and classification in Australia. Vegetatio 118, 81-101. doi: 10.1007/BF00045192

Pringle, C. (2003). What is hydrologic connectivity and why is it ecologically important? Hydrol. Process. 17, 2685-2689. doi: 10.1002/hyp.5145

Radinger, J., Essl, F., Hölker, F., Horký, P., Slavík, O., and Wolter, C. (2017). The future distribution of river fish: the complex interplay of climate and land use changes, species dispersal and movement barriers. Glob. Change Biol. 23, 4970-4986. doi: 10.1111/gcb.13760

Ramsar (2016). An Introduction to the Ramsar Convention on Wetlands, 7th Edn. (Previously The Ramsar Convention Manual), 7th Edn. Gland: Ramsar Convention Secretariat.

Reynolds, C., Miranda, N. A. F., and Cumming, G. S. (2015). The role of waterbirds in the dispersal of aquatic alien and invasive species. Divers. Distribut. 21, 744-754. doi: 10.1111/ddi.12334

Reynolds, L. F. (1983). Migration patterns of five fish species in the Murray-darling river system. Aust. J. Mar. Freshw. Res. 34, 857-871. doi: 10.1071/MF9830857

Roberts, J. H., Anderson, G. B., and Angermeier, P. L. (2016). A long-term study of ecological impacts of river channelization on the population of an endangered fish: lessons learned for assessment and restoration. Water 8:240. doi: 10.3390/w8060240

Roshier, D. A., and Reid, J. R. W. (2002). Broad Scale Processes in Dynamic Landscapes and the Paradox of Large Populations of Desert Waterbirds. Lymm: Iale Int Assoc Landscapeecol.

Roshier, D. A., Robertson, A. I., Kingsford, R. T., and Green, D. G. (2001). Continental-scale interactions with temporary resources may explain the paradox of large populations of desert waterbirds in Australia. Landscape Ecol. 16, 547-556. doi: 10.1023/A:1013184512541

Savenije, H. H. G., Hoekstra, A. Y., and van der Zaag, P. (2014). Evolving water science in the Anthropocene. Hydrol. Earth Syst. Sci. 18, 319-332. doi: 10.5194/hess-18-319-2014

Shafroth, P. B., Schlatter, K. J., Gomez-Sapiens, M., Lundgren, E., Grabau, M. R., Ramirez-Hernandez, J., et al. (2017). A large-scale environmental flow experiment for riparian restoration in the Colorado River Delta. Ecol. Eng. 106, 645-660. doi: 10.1016/j.ecoleng.2017.02.016

Shendryk, I., Broich, M., Tulbure, M. G., McGrath, A., Keith, D., and Alexandrov, S. V. (2016). Mapping individual tree health using full-waveform airborne laser scans and imaging spectroscopy: a case study for a floodplain eucalypt forest. Remote Sens. Environ. 187, 202-217. doi: 10.1016/j.rse.2016.10.014

Sklar, F. H., Fitz, H. C., Wu, Y., Van Zee, R., and McVoy, C. (2001). The design of ecological landscape models for Everglades restoration. Ecol. Econ. 37, 379-401. doi: 10.1016/S0921-8009(01)00180-X

Soranno, P. A., Cheruvelil, K. S., Webster, K. E., Bremigan, M. T., Wagner, T., and Stow, C. A. (2010). Using landscape limnology to classify freshwater ecosystems 
for multi-ecosystem management and conservation. Bioscience 60, 440-454. doi: 10.1525/bio.2010.60.6.8

Souchon, Y., Sabaton, C., Deibel, R., Reiser, D., Kershner, J., Gard, M., et al. (2008). Detecting biological responses to flow management: missed opportunities; future directions. River Res. Appl. 24, 506-518. doi: 10.1002/rra.1134

Stendera, S., Adrian, R., Bonada, N., Canedo-Arguelles, M., Hugueny, B., Januschke, K., et al. (2012). Drivers and stressors of freshwater biodiversity patterns across different ecosystems and scales: a review. Hydrobiologia 696, 1-28. doi: 10.1007/s10750-012-1183-0

Stewardson, M., and Guarino, F. (2018). Basin-scale environmental water delivery in the Murray-Darling, Australia: a hydrological perspective. Freshwater Biol. 63, 969-985. doi: 10.1111/fwb.13102

Stewardson, M. J., Shang, W., Kattel, G., and Webb, J. A. (2017). “Environmental water and integrated catchment management," in Water for the Environment: From Policy and Science to Implementation and Management, eds A. C. Horne, J. A. Webb, M. J. Stewardson, B. Richter, and M. Acreman. (London: Academic Press), 519-538.

Stoffels, R. J., Clarke, K. R., Rehwinkel, R. A., and McCarthy, B. J. (2014). Response of a floodplain fish community to river-floodplain connectivity: natural versus managed reconnection. Can. J. Fish. Aquat. Sci. 71, 236-245. doi: $10.1139 /$ cjfas-2013-0042

Stoffels, R. J., Rehwinkel, R. A., Price, A. E., and Fagan, W. F. (2016). Dynamics of fish dispersal during river-floodplain connectivity and its implications for community assembly. Aquat. Sci. 78, 355-365. doi: 10.1007/s00027-015-0437-0

Summers, M. F., Holman, I. P., and Grabowski, R. C. (2015). Adaptive management of river flows in Europe: a transferable framework for implementation. J. Hydrol. 531, 696-705. doi: 10.1016/j.jhydrol.2015.10.057

Swirepik, J. L., Burns, I. C., Dyer, F. J., Neave, I. A., O’Brien, M. G., Pryde, G. M., et al. (2016). Establishing environmental water requirements for the murraydarling basin, Australia's largest developed river system. River Res. Appl. 32, 1153-1165. doi: 10.1002/rra.2975

Talley, T. S. (2007). Which spatial heterogeneity framework? Consequences for conclusions about patchy population distributions. Ecology 88, 1476-1489. doi: 10.1890/06-0555

Thiem, J. D., Wooden, I. J., Baumgartner, L. J., Butler, G. L., Forbes, J. P., and Conallin, J. (2017). Recovery from a fish kill in a semi-arid Australian river: can stocking augment natural recruitment processes? Aust. Ecol. 42, 218-226. doi: $10.1111 /$ aec.12424

Thorp, J. H. (2014). Metamorphosis in river ecology: from reaches to macrosystems. Freshw. Biol. 59, 200-210. doi: 10.1111/fwb.12237

Thorp, J. H., Thoms, M. C., and Delong, M. D. (2006). The riverine ecosystem synthesis: biocomplexity in river networks across space and time. River Res. Appl. 22, 123-147. doi: 10.1002/rra.901

Trabucchi, M., Ntshotsho, P., O’Farrell, P., and Comín, F. A. (2012). Ecosystem service trends in basin-scale restoration initiatives: a review. J. Environ. Manage. 111, 18-23. doi: 10.1016/j.jenvman.2012.06.040

van Coller, A. L., Rogers, K. H., and Heritage, G. L. (2000). Riparian vegetationenvironment relationships: complimentarity of gradients versus patch hierarchy approaches. J. Vegetation Sci. 11, 337-350. doi: 10.2307/3236626

van den Belt, M., and Blake, D. (2015). Mediated modeling in water resource dialogues connecting multiple scales. J. Am. Water Resour. Assoc. 51, 1581-1599. doi: 10.1111/1752-1688.12330

Vannote, R. L., Minshall, G. W., Cummins, K. W., Sedell, J. R., and Cushing, C. E. (1980). River continuum concept. Can. J. Fish. Aquat. Sci. 37, 130-137. doi: $10.1139 /$ f80-017

Vietz, G. J., and Finlayson, B. L. (2017). "Geomorphological effects of flow alteration on rivers," in Water for the Environment: From Policy and Science to Implementation and Management, eds A. C. Horne, J. A. Webb, M. J. Stewardson, B. Richter, and M. Acreman. (London: Academic Press), 83-97.
Vorosmarty, C. J., Meybeck, M., and Pastore, C. L. (2015). Impair-then-repair: a brief history \& global-scale hypothesis regarding human-water interactions in the anthropocene. Daedalus 144, 94-109. doi: 10.1162/DAED_a_00345

Vorosmarty, C. J., Pahl-Wostl, C., Bunn, S. E., and Lawford, R. (2013). Global water, the anthropocene and the transformation of a science. Curr. Opin. Environ. Sustain. 5, 539-550. doi: 10.1016/j.cosust.2013.10.005

Vorosmarty, C. J., and Sahagian, D. (2000). Anthropogenic disturbance of the terrestrial water cycle. Bioscience 50, 753-765. doi: 10.1641/0006-3568(2000)050[0753:ADOTTW]2.0.CO;2

Walker, K. F., Boulton, A. J., Thoms, M. C., and Sheldon, F. (1994). Effects of water-level changes induced by weirs on the distribution of littoral plants along the river murray, South-Australia. Aust. J. Mar. Freshwater Res. 45, 1421-1438. doi: 10.1071/MF9941421

Watts, R. J., Kopf, R. K., McCasker, N., Howitt, J. A., Conallin, J., Wooden, I., et al. (2018). Adaptive management of environmental flows: using irrigation infrastructure to deliver environmental benefits during a large hypoxic blackwater event in the Southern Murray-Darling Basin, Australia. Environ. Manage. 61, 469-480. doi: 10.1007/s00267-017-0941-1

Wedderburn, S. D., Hillyard, K. A., and Shiel, R. J. (2013). Zooplankton response to flooding of a drought refuge and implications for the endangered fish species Craterocephalus fluviatilis cohabiting with alien Gambusia holbrooki. Aquat. Ecol. 47, 263-275. doi: 10.1007/s10452-013-9442-3

Wen, L., Saintilan, N., Reid, J. R., and Colloff, M. J. (2016). Changes in distribution of waterbirds following prolonged drought reflect habitat availability in coastal and inland regions. Ecol. Evol. 6, 6672-6689. doi: 10.1002/ece3.2091

Whitworth, K. L., and Baldwin, D. S. (2016). Improving our capacity to manage hypoxic blackwater events in lowland rivers: the blackwater risk assessment tool. Ecol. Model. 320, 292-298. doi: 10.1016/j.ecolmodel.2015. 10.001

Whitworth, K. L., Baldwin, D. S., and Kerr, J. L. (2012). Drought, floods and water quality: drivers of a severe hypoxic blackwater event in a major river system (the southern Murray-Darling Basin, Australia). J. Hydrol. 450, 190-198. doi: 10.1016/j.jhydrol.2012.04.057

Wilson, K. A., Underwood, E. C., Morrison, S. A., Klausmeyer, K. R., Murdoch, W. W., Reyers, B., et al. (2007). Conserving biodiversity efficiently: what to do, where, and when. PLoS Biol. 5:e0050223. doi: 10.1371/journal.pbio.0050223

Wingard, G. L., and Lorenz, J. J. (2014). Integrated conceptual ecological model and habitat indices for the southwest Florida coastal wetlands. Ecol. Indic. 44, 92-107. doi: 10.1016/j.ecolind.2014.01.007

Young, P. S., Cech, J. J., and Thompson, L. C., (2011). Hydropower-related pulsed-flow impacts on stream fishes: a brief review, conceptual model, knowledge gaps, and research needs. Rev. Fish Biol. Fish. 21, 713-731. doi: 10.1007/s11160-011-9211-0

Ziv, G., Baran, E., Nam, S., Rodríguez-Iturbe, I., and Levin, S. A. (2012). Tradingoff fish biodiversity, food security, and hydropower in the Mekong River Basin. Proc. Natl. Acad. Sci. U.S.A. 109, 5609-5614. doi: 10.1073/pnas.1201 423109

Conflict of Interest Statement: The authors declare that the research was conducted in the absence of any commercial or financial relationships that could be construed as a potential conflict of interest.

Copyright (c) 2018 Gawne, Capon, Hale, Brooks, Campbell, Stewardson, Grace, Stoffels, Guarino and Everingham. This is an open-access article distributed under the terms of the Creative Commons Attribution License (CC BY). The use, distribution or reproduction in other forums is permitted, provided the original author(s) and the copyright owner(s) are credited and that the original publication in this journal is cited, in accordance with accepted academic practice. No use, distribution or reproduction is permitted which does not comply with these terms. 